\title{
On a New Species of Earthworm from a Mexican Cave ${ }^{\mathbf{1}}$ )
}

\author{
By Gordon Gates ${ }^{2}$ )
}

A hitherto unknown earthworm was present in some of the various cave collections secured by J. Reddell and his associates. Whether the species will be of special interest to speleologists cannot be determined from available information.

\section{EODRILUS MEXICANUS n.sp.}

Mexico: San Luis Potosi. Sotano de Tlamaya, crawling in silt at bottom of pools of stream 950 feet below entrance to the cave, November 28, 1964, 6-0-0. T. Raines, W. Bell per J. Reddell. Rimstone pools, about 1,000 feet below the entrance July 2, 1965, 11-0-0. J. Fish, T. Raines per J. Reddell.

External characteristics. Length (contracted), 67-76 mm. (1964), 56-93 (1965). Diameter, 4-5 mm. (1964), 3-4 mm. (1966). Segments, 100, 103 (posterior amputees), 112, 117 (posterior amputee?), 119, 120, 121 (2 specimens), 122, 123 (3), 124 (2), 125, 128, specimens with tail regenerates ( $c f$. below) have 115 and 125 segments. Soma, nearly circular in cross section anteriorly, elliptical posteriorly and with right-left: dorso-ventral diameter: $2: 1$. Anus, terminal, a vertical slit. Color, none, white after preservation, in vivo "perfectly transparent" according to the collectors. Even after several days preservation in strong formalin, every loop in the dorsal trunk was distinctly outlined against a dark background provided by the vascularization of the gut wall and the ingesta. Prostomium, broad, perhaps to be characterized as prolobous though seemingly (some specimens) slightly indenting segment i. The latter condition, in the past, presumably would have been called proepilobous. However, in the present specimens, differences appear to vary with condition and to be too small to be worth recording, especially when the anterior end (as in most of these worms) is softened and/or eroded. The transverse furrow demarcating the prostomium from $i$, in each specimen, is obvious. Se-

1) From research financed by the National Science Foundation.

2) University of Maine, Orono (U.S.A.). 
condary annulation, a slightly protuberant setal annulus usually demarcated posteriorly by a faint secondary furrow, a presetal secondary furrow, sometimes not distinguishable. Dorsal pores, none.

Setae, eight per segment, closely paired, present from ii, $a, b / x v i i$, xix penial and their follicle apertures more closely paired, $a, b /$ xviii lacking (?), $A B=C D, A A$ ca. $=B C$ but one or the other may be slightly smaller, $D D$ ca. $=$ or $>1 / 2 \mathrm{C}$. When the last few segments are almost transversely oblong in cross section, as sometimes happens, the ventral couples are on the ventral side and the dorsal couples are at the ventral corners. Nephropores, inconspicuous, in a single rather irregular rank on each side, at or just in front of the presetal secondary furrow, anteriorly somewhat median to $C$, gradually becoming more ventral posteriorly but still lateral to $B$.

Spermathecal pores, minute, superficial, two pairs, at $B$ and $7 / 8-8 / 9$. (Female pores, at $B$ and nearer 13/14 than eq/xiv?) A longitudinally deep depression (one specimen, second lot), extends from the postsetal secondary furrow of xiv to 19/20. Apertures of $a$ and $b$ follicles of $\mathrm{xv}-\mathrm{xix}$ are on the lateral walls dorsally of the depression. Rudiments of seminal grooves between equators of xvii and xix may be present.

Internal anatomy. Septa, present from 4/5, 5/6-13/14 muscular. Pigment, none. At $\mathrm{mD}$ there is no special longitudinal muscle band. In the body wall immediately under intersegmental furrows at $\mathrm{mD}$, there is no weakening of the musculature as in various species that erroneously have been thought to have dorsal pores. Although setal follicles of each pair are adherent to each other entally, passage into and through the body wall is discrete. Additional to those 8 indicated by the follicles, there are no other gaps in the longitudinal musculature. The subpharyngeal and subesophageal horizontal mesenteries are present and as usual, except that in some worms the two appeared to be continous.

The longitudinal musculature is of a fasciculate kind according to Prof. W. J. Harman who characterizes it as follows. "Typically in $A A$ there is one big bundle (Kastchen) internally fasciculated into smaller bundles containing 4-17 muscle fibers. The region of $B C$ is divided into 5 major bundles that are internally fasciculated. The number of fibres is $2-20$ but the latter is more characteristic. $D D$ is divided into approximately 20 internally fasciculated Kastchen. Each is small and middorsally $300 \mu$ wide, with small fascicles containing 3-20 individual fibers. Fascicles are more numerous, smaller, and more discrete dorsally. These muscle bundles resemble those of Pheretima diffringens (Baird, 1869) and more closely resemble vertebrate muscle than any other earthworm I have seen." 
Gizzard, none (15). Esophagus, with low longitudinal ridges (not lamelliform) internally in xiii-xv. Calciferous lamellae, none. Intestinal origin, apparently in $\mathrm{xv}(5)$, apparently in $\mathrm{xvi}$ just behind $15 / 16$ (9). An abrupt widening of the gut just behind 16/17 does produce an appearance in one worm as of an intestinal origin in xvii but the gut is constricted at insertion of $17 / 18$. The gut portion in xvii has the gizzard-like resemblance mentioned below and is filled with food which may have been responsible for the distention. Condition did not permit macroscopic recognition of histological characters of tissues in the region around supposed location of the esophageal valve. A beadshaped portion of the gut may seem rather gizzard-like in several places, e.g., in xxiv, xxix, xxxv, xxxvii, xlii, lxv of one worm, the color at first glance resembling the pinkish sheen of muscles but actually due to presence of blood, the widening often not associated with presence of food. Typhlosole, beginning in region of $\mathrm{xv}-\mathrm{xx}$, simply lamelliform, often gorged with blood and then almost black, becoming quite low posteriorly, ending in the region of the 108th to 114th segments (Table 1) leaving 9 to 20 atyphlosolate. A fairly tough membrane, presumably peritrophic, in some worms, enclosed the ingesta of a posterior portion of the intestine. Much of the gut in other worms was empty or nearly so.

Table 1

Typhlosole termination and segment number in Eodrilus mexicanus

\begin{tabular}{ccccc}
\hline $\begin{array}{c}\text { Serial } \\
\text { number }\end{array}$ & $\begin{array}{c}\text { Typhlosole } \\
\text { ends in segment }\end{array}$ & $\begin{array}{c}\text { Atyphlosolate } \\
\text { segments }\end{array}$ & $\begin{array}{c}\text { Total number } \\
\text { of segments }\end{array}$ \\
\hline 1 & 108 & 9 & 117 & (posterior \\
2 & 108 & 20 & 128 & amputee?) \\
3 & 109 & 12 & 121 & \\
4 & 112 & 12 & 124 & \\
5 & 114 & 10 & 124 &
\end{tabular}

The typhlosole of one worm, behind the 78 th of 125 segments, seemingly was interrupted by irregular gaps in which little or no trace of the structure was distinguishable. Because of a similar condition in other worms, determination of typhlosole terminations was abandoned.

Dorsal trunk, much longer than the body and looped, single throughout, or double in xi-xvi (1), in xvi and xxi (1), bifurcating just behind the brain, the branches passing ventrally along with the nervous commissures. Ventral trunk, complete, bifurcating over the subpharyngeal ganglion. Supra-esophageal, in $\mathrm{x}$-xiv. Extra-esophageals, median to 
hearts, probably passing back into xii or xiii at least but empty in a posterior portion of varying length and then not traceable. Subneural, not a trace found on parietes or on ventral surface of nerve cord from one end of the body to the other. Hearts, of $x$-xiii latero-esophageal, of vii-ix lateral, in vi-v not found. Last hearts, in xiii (15). Two longitudinal vessels (or spaces) are present in the floor of the intestine close to $\mathrm{mV}$. When gorged with blood they are indicated by externally visible, longitudinal, dark red ridges corresponding to a pair of whitish longitudinal ridges on the floor of the gut internally. When the typhlosole is gorged with blood, in a group of segments, the ventral vessels (or spaces) are not.

Nephridia, avesiculate. Short loops of the thicker portion are in region of $C D$ and/or a lateral portion of $B D$. A long hairpin loop of the thinner portion reaches laterally and dorsally almost to $\mathrm{mD}$. The slender duct, rarely distinguishable, seems to pass into the parietes at probable site of nephropore and so is believed to continue straight through the body wall. The neck is slender, transparent and unrecognizable except in front of a septum where the small funnel is in the region of $A B$.

Andry, not determined. Seminal vesicles, acinous, in xi, xii. Gonoducal funnels, four pairs, in $x$-xiv. At proper sites for vesicles or ovisacs in xiii, a pair of sacs, smaller than the ovisacs.

Prostates, tubular, looped, juvenile, confined to xvii and xix. Penial setae, two in each follicle, a functional and a reserve that is more than half as long as the other. Shafts long, slender, gradually tapering ectally to an almost hair-like state. Ornamentation, of a few shortly triangular teeth. They are so large relative to setal width as to reach entirely across the portion of the shaft that is in view under the microscope. A terminal distal portion is usually wrinkled. Shafts protruding to the exterior occasionally are just visible under the binocular.

Spermathecae, in viii-ix, at best development fairly large, reaching up to level of dorsal face of gut. Duct, shorter than ampulla. Diverticulum, sessile, ellipsoidal, transversely placed across anterior face of duct, opening into the duct by a middle portion. The dorsal margin of ampullae may be more or less deeply incised to produce a bi-, tri- even a quadri-lobed appearance. The ventral margin of each spermathecae of another worm was lobulated. Ovaries, fan-shaped, with several short egg strings. Ovisacs, in xiv, lobed, fairly large.

Ventral follicles beginning with vii, viii, or ix, to xvi, protrude further into the coelom. They appear to be enlarged. Protrusion decreases posteriorly in the series. 
Reproduction. The worms are considered to be in late juvenile and early adolescent stages. Macroscopically recognizable evidence of sperm maturation was seen only once-several small flecks of spermatozoal iridescence on the male funnels that were much better developed than in the other specimens. Copulation had not taken place. Organ deformations, reductions, or eliminations, such as often are associated with parthenogenesis seemingly are lacking. Accordingly, amphimixis is anticipated.

Development. First externally recognizable signs of adolescence are found in the region where some sort of a male field eventually will appear. Apertures of $a, b$ follicles in each pair of xvii-xix are closer to each other than in adjacent segments. Ventral setae of those segments still may be protuberant and so visible from the exterior or those of 18 only may be invisible or all ventral setae in xvii-xix may be unrecognizable.

Regeneration. (1) Tail regenerate of 11 segments at 104/105. (2) Tail regenerate of 9 segments at $116 / 117$. Of course the number of amputated segments is unknown but comparison with the segment numbers of normal, unamputated individuals ( $c f . p .63)$ indicates that in this species and at certain posterior levels, caudal regeneration may be nearly if not actually equimeric or hypermeric.

Ingesta. Coagulum of the intestinal lumen has a pink tinge. Rock particles were not recognized. Even under higher power of the optical miscroscope about all that could be seen were small bits and pieces of nondescript shapes that presumably were organic. Scattered here and there (some specimens) was an occasional black fleck that looked as if it might be mineral. These worms appear to be discriminate feeders.

Abnormality. One spermatheca of ix (1 worm) had been doubled. The extra organ was located immediately lateral to the normal position.

Habitat. None of these worms were found in the mud "despite intensive search" for them, according to the collector's notes. Nothing is known about the megadrile fauna outside of the cave entrance.

Parasites. Coelomic cavities of the last 8 segments of one worm were filled with bits of brown debris. Similar debris in two other worms had been aggregated into "brown bodies." The latter comprised in descending order of frequency: brown corpuscles, small pseudonavicella-shaped spores, miscellaneous unknown organisms, setae, nematode eggs (1), in the second worm, brown corpuscles, other-sized pseudonavicella-shaped spores. White "brown bodies" were present in $\mathrm{x}, \mathrm{xi}$ of one individual and coelomic cavities in $\mathrm{x}$-xiii of another 
worm were filled with similar bodies. Parasites were not recognized therein. Gregarine trophozoites and nematodes were not seen in any of the 15 dissected specimens.

Systematics. The Mexican worms can go equally well into the acanthrodrilid genus Eodrilus as defined by Michaelsen (1907) or by Pickford (1937) or into Acanthodrilus as defined by Stephenson (1930). In either case, the taxon has species in Australia, New Zealand, Central America and Mexico, Cuba, Cameroons, South Africa, and Madagascar. None of those species has been suspected of profiting from transoceanic carriage by man. Accordingly, the distribution alone suggests the polyphyly that is so typical of the classical system of the Oligochaeta. The literature records a morphological heterogeneity that now seems unlikely to characterize, at generic level, any group of monophyletic origin. Thus, Eodrilus appears to be another one of the congeries that were regarded as genera in the classical system. American taxa of the Eodrilus congeries alone now need to be considered. The genus always has been defined as having holoic (meganephridial in the classical terminology) nephridia. Three species, eiseni, irpex and tecum-umami Michaelson, 1911, now are known to have meroic (i.e., micronephridial in the classical terminology) nephridia. By definition those three species belong in another family, the Octochaetidae. There they now are in a somewhat less heterogenous group, Ramiellona Michaelsen, 1935 (cf. Gates, 1962). Of forms with holoic nephridia, five, crystallifer (Eisen, 1900), divergens (Cognetti, 1905), hamiger Michaelsen, 1911, salvadorensis Graff, 1957, tamajusi (Eisen, 1896) appear to have well developed calciferous glands. Those taxa, accordingly, need no further consideration here. Calciferous tissues were not observed in haffneri and zilchi Graff, 1957, though well developed intramural glands could have been overlooked in each of those species unless sections (free hand or microtome) of the esophagus were examined.

The cave form differs from haffneri, oxkutzcabensis Pickford, 1938, vasliti and whitmanni (Eisen, 1900) as well as zilchi, by having a pair of hearts in xiii of each dissected specimen. Intraspecific variation as to presence or absence of hearts in xiii of megadrile oligochaetes now seems to be so very rare, at least in normal individuals, as to warrant considerable usefulness of the characters in earthworm systematics. The vascular system of E.ulrici (Michaelsen, 1923) was not mentioned in the published description of that species. However, the Cuban form is adequately distinguished from the Mexican by: presence of a large gizzard in segment $\mathrm{v}$, absence of a typhlosole, presence of dorsal pores, as well as by spermathecal and other characters. The Mexican cave worms accordingly belong to a hitherto undescribed species. 
Lack of information about much important structure in other American species of Eodrilus contraindicates estimating intrageneric relationships of E.mexicanus. Close interspecific relationships are more likely to be evidenced by the genitalia than by somatic anatomy. Yet, in spite of the elassical emphasis on genital systems, information still is needed, especially about individual variation in characters long thought to be of systematic importance. Presence of seminal vesicles in xi and xii of E.mexicanus, after loss of ancestral pairs in ix-x, indicates a phylogeny different from that of oxkutzcabensis which had lost the pairs of $\mathrm{x}$-xi. The ancestral four pairs still characterize E. haffneri and perhaps one or two other species.

Remarks. Gonoducal funnels of xii were not sufficiently developed to warrant a decision as to whether they are male or female. According to classical authorities, gonads of xii ought to be female, in which case sacs on the posterior face of $12 / 13$ will be ovisacs. Presence of ovaries in xii, again according to classical authorities, can be considered either as retention of a primitive ancestral character (Michaelsen) or as reversion (Stephenson) to a long lost former state. Even if ancestral gonads of xii were female, their change to male now seems with in range of possibilities. However, hologyny rather than hyperandry is anticipated for E.mexicanus. Functional holandry in group II megadriles has been recorded (Gates, 1958) for an amphimictic species only once and then in a Texan species of the Acanthodrilid American genus Diplocardia.

An answer to the question asked by Reddell, "Is the transparency an adaptation to the cave life?" at present is impossible. No information is available as to condition of body wall with reference to transparency or opacity for any American species of Eodrilus.

\section{SUMMARY}

Eodrilus mexicanus of the megadrile oligochaete family Acanthodrilidae is described along with some data as to development, regeneration and abnormality. Relationships with its American congeners, often inadequately characterized, are discussed and the present state of Eodrilus systematics is criticised. E.mexicanus seems likely to be of unusual interest as the second species of earthworm to have ovaries in segment xii.

\section{RÉSUMÉ}

Description de Eodrilus mexicanus, nouvelle espèce d'Oligochète Mégadrilide de la famille des Acanthodrilidae, accompagnée de quelques renseignements concernant le développement, la régénération et une anomalie. 
Les affinités de cette espèce avec ses congénères américains, souvent insuffisamment caractérisés, sont discutées; le présent statut de la systématique des Eodrilus est critiqué. E.mexicanus est sans aucun doute d'un intérêt tout particulier car c'est la seconde espèce d'Oligochètes à avoir des ovaires dans le segment XII.

\section{REFERENCES}

Gates, G. E. (1958) - On a hologynous species of the earthworm genus Diplocardia, with comments on Oligochaete Hologyny and "Consecutive Hermaphroditism." American Museum of Natural History Novitates, 1886: 1-9.

- (1962) - On some earthworms of Eisen's collection. Proceedings of the California Academy of Sciences, (4), 31: 185-225.

Michaelsen, W. (1907) - Oligochaeta. In: Die Fauna Südwest-Australiens. Ergebn. Hamburg. Südwest-australische Forschungsr., 1905, 27.

Pick ford, G. (1937) - A monograph of the Acanthodriline earthworms of South Africa. Cambridge, W. Heffer \& Sons, Ltd., 1-612.

Stephenson, J. (1930) - The Oligochaeta. Oxford, Clarendon Press, 1-978. 